\title{
Isolation, characterisation and DNA analysis of Mycoplasma spp. from moribund prawns Penaeus monodon cultured in Australia
}

\author{
Ali Ghadersohi, Leigh Owens* \\ Department of Microbiology and Immunology, Australian Institute of Tropical Veterinary and Animal Science, \\ James Cook University, Townsville, Queensland 4811, Australia
}

\begin{abstract}
For the first time, a total of 14 Mycoplasma isolates were cultured from 24 moribund prawns investigated during an outbreak of mid-crop mortality syndrome in northern Queensland, Australia. Mycoplasma were isolated from the gill appendages, brains and eyes of the prawns. Mycoplasma growth occurred between 20 and $37^{\circ} \mathrm{C}$ with or without $\mathrm{CO}_{2}$ in modified Frey's medium containing 0.5 to $3.0 \%$ sodium chloride and $20 \%$ foetal bovine serum. Optimal growth was observed at $37^{\circ} \mathrm{C}$ with $5 \% \mathrm{CO}_{2}$. All strains were size filtered and cloned, and their morphology, biochemical and biomolecular characteristics were compared with the characteristics of previously described Mycoplasma species. The results showed that these strains belonged to 2 new species, for which the temporary names Mycoplasma P1 (MP1) and Mycoplasma P2 (MP2) were designated. Both Mycoplasma fermented most of the tested carbohydrates but did not hydrolyse arginine and urea. MP1 produced films and spots and had high phosphatase activity, but MP2 did not produce films or spots and had no phosphatase activity. Both species lysed sheep erythrocytes. A genomic library (Mbo1 digested) was prepared from MP1 DNA and cloned into pUC19. Colony hybridisation, using a probe prepared from purified MP1, was used to identity colonies of interest. MP1 DNA fragments were retrieved from recombinant plasmids by digestion with EcoRI and HindIII. This DNA was used to prepare randomly primed probes for dot blot hybridisation analysis with immobilised DNA from MP1. MP2, $M$. bovis, $M$. dispar, $M$. agalactiae, $M$. bovigenitalium, $M$. ovipneumoniae, Mycoplasma Group 7 , $M$. arginini and bacteria belonging to different genera. The probe reacted with genomic DNA from MP1 only. To further enhance the sensitivity, an MP1 specific polymerase chain reaction (PCR) assay was designed and produced a 254 bp amplicon which discriminated MP1 from all other Mycoplasma DNA tested. Using the DNA probe and PCR assay, most of the Mycoplasma isolated from the diseased prawns could be designated as strain MP1 $(11 / 14,-80 \%)$
\end{abstract}

KEY WORDS: Penaeus monodon - Mycoplasma Polymerase chain reaction - DNA probe Diagnosis bacteria

\section{INTRODUCTION}

Mycoplasmas of aquatic animals have not been studied extensively. Nevertheless, Mycoplasma mobile has been isolated from diseased fish species showing symptoms of red disease (Kirchhoff et al. 1987), and $M$. phocarhinis and $M$. phocacerebrale have been reported from harbor seals (Giebel et al. 1991) suffer-

\footnotetext{
-Addressee for correspondence.

E-mail: leigh.owens@jcu.edu.au
}

ing from an acute and fatal disease. In 1994, midcrop mortality syndrome (MCMS) spread through the Penaeus monodon aquaculture industry in northern Queensland, Australia. In a study of filterable agents that might be involved in the mortalities, it was necessary to determine if Mycoplasma might have a role in MCMS. Two different Mycoplasma were isolated from a number of the diseased prawns from 2 affected farms. We report for the first time the isolation details of these strains, describe the taxonomic evaluation of the 2 strains and compare them with previously described species of Mollicutes. 


\section{MATERIALS AND METHODS}

Prawns. Isolation of Mycoplasma was performed on 24 prawns found moribund or dead at the edges of ponds from 2 aquaculture farms in northern Queensland. Prawns were tested either within $2 \mathrm{~h}$ postmortem or after storage at $-20^{\circ} \mathrm{C}$.

Mycoplasma strains, bacteria and growth conditions. Most of the reference Mycoplasma strains were obtained from the National Collection of Type Cultures (Colindale, UK), but some strains were obtained from Oonoonba Veterinary Laboratory of Northern Queensland (Table 1). Other bacterial strains were obtained from our Department. All Mycoplasma strains were grown in Frey's medium (Frey et al, 1968) containing 20 or $30 \%$ foetal bovine serum (FBS), depending upon the requirement of individual species. Other bacterial strains were grown in brain heart infusion (BHI) medium.

Mycoplasma medium. Mycoplasma Frey's medium (Frey et al. 1968) with some modifications was used for isolation of Mycoplasma from the diseased prawns. Briefly, mycoplasma broth medium (MBM) was pre-

Table 1. Mycoplasma and other bacteria species tested by the MP1 specific probe and PCR. NC: type strain NCTC, National Collection of Type Culture; Oonoonba: Oonoonba Veterinary Laboratory of Northern Queensland; JCU: Department of Microbiology and Immunology, James Cook University

\begin{tabular}{|ll|}
\hline Species & Strain \\
\hline Mycoplasma bovis & NC10131 \\
Mycoplasma ovipneumoniae & NC10151 \\
Mycoplasma agalactia & NC10123 \\
Mycoplasma bovigenitalium & NC10122 \\
Mycoplasma bovirhinis & NC10118 \\
Mycoplasma dispar & NC101125 \\
Mycoplasma Group 7 & Oonoonba \\
Mycoplasma bovigenitalium & Oonoonba \\
Mycoplasma arginini & Oonoonba \\
Vibrio spp. & JCU \\
Pseudomonas putida & JCU \\
Staphylococcus aureus & JCU \\
Staphylococcus spp. & JCU \\
Streptococcus uberis & JCU \\
Streptococcus agalactia & JCU \\
Corynebacterium bovis & JCU \\
Klebsiella pneumoniae & JCU \\
Pseudomonas spp. & JCU \\
Pasteurella spp. & JCU \\
Aeromonas spp. & JCU \\
Brucella abortus & JCU \\
Yersinia enterocolitica & JCU \\
Enterobacter cloacae & JCU \\
Enterobacter facalis & JCU \\
Serratia marcessans & JCU \\
Bacillus subtilis & JCU \\
Escherichia coli & JCU \\
& \\
\hline
\end{tabular}

pared by rehydrating $12.75 \mathrm{~g}$ of mycoplasma broth base (Oxoid Laboratories) in $500 \mathrm{ml}$ of $\mathrm{dH}_{2} \mathrm{O}$ containing $2.5 \mathrm{ml}$ of $0.4 \%$ phenol red and $1.25 \mathrm{ml}$ of $10 \%$ thallium acetate. The medium was adjusted to $\mathrm{pH} 7.8$ and autoclaved at $121^{\circ} \mathrm{C}$ at $15 \mathrm{lbs}$ (ca $6.8 \mathrm{~kg}$ ) pressure for $15 \mathrm{~min}$. It was dispensed in $80 \mathrm{ml}$ volumes and stored at $-20^{\circ} \mathrm{C}$. The following filter sterilised solutions were added to each $80 \mathrm{ml}$ of MBM: $20 \mathrm{ml}$ FBS (Commonwealth Serum Laboratory, Melbourne, Australia), $1 \mathrm{ml}$ of freshly prepared yeast extract solution (Herderschee 1963), $1 \mathrm{ml}$ of $0.2 \%$ DNA solution (sodium salt isolated from salmon testes) (Sigma Chemical Co., St. Louis); $1 \mathrm{ml}$ of $10 \%$ glucose solution, $1 \mathrm{ml}$ of $10 \mathrm{mg} \mathrm{ml}^{-1}$ of ampicillin solution.

To prepare Mycoplasma agar (MA), technical agar (Oxoid) was added to the MBM to a final concentration of $1 \%$ without phenol red and glucose and autoclaved as described above. Once the temperature of the medium had reached about $40^{\circ} \mathrm{C}$ in a water bath, the following filter sterilised solutions were added to each $80 \mathrm{ml}$ of $\mathrm{MA}$, mixed well and dispensed into $5 \mathrm{ml}$ petri dishes: $20 \mathrm{ml} \mathrm{FBS,} 1 \mathrm{ml}$ of yeast extract solution, $1 \mathrm{ml}$ of $0.2 \%$ salmon testes DNA solution, $1 \mathrm{ml}$ of $10 \mathrm{mg} \mathrm{ml}^{-1}$ of ampicillin solution.

For the isolation of arginine-requiring Mycoplasma and Ureaplasma, modified media were used. To prepare these, $1 \%$ arginine hydrochloride or urea was added to MBM and adjusted to $\mathrm{pH}$ 7.0. The shift of the phenol red indicator from pink to red indicated growth in this medium.

Culture procedure. Approximately $0.5 \mathrm{~g}$ of homogenised organ material (gill appendages, brain and eyes) from individual prawns was suspended in $3 \mathrm{ml}$ of MBM. Once a homogenous suspension had been produced, it was diluted in MBM. Aliquots of $300 \mu$ of suspension were used to prepare serial 10-fold dilutions (up to $10^{-4}$ ) in $\mathrm{MBM}$ and modified arginine broth (MAB). To test for any Mycoplasma contamination in the FBS and other sources, 1 tube containing MBM was always put up as a negative control. The tubes were incubated at $37^{\circ} \mathrm{C}$ in rolling drums in which the tubes rotated once per minute. They were examined daily for $\mathrm{pH}$ (colour) changes. Whenever the colour of the medium turned to yellow, $300 \mu$ l of the culture was transferred to a fresh tube containing $3 \mathrm{ml}$ of fresh MBM. After 6 to $7 \mathrm{~d}, 50 \mu \mathrm{l}$ of the contents of each tube with the highest dilution indicating growth was spotted into MA plates. The plates were incubated at $37^{\circ} \mathrm{C}$ for $14 \mathrm{~d}$ in a humidified atmosphere with $5 \% \mathrm{CO}_{2}$. They were examined for colonies using an inverted microscope (Olympus CK2, Japan). Differences in growth of Mycoplasma on plates incubated aerobically and in $5 \% \mathrm{CO}_{2}$ were recorded. The cellular morphology of the organisms was assessed by light microscopy after Gram and Giemsa staining. 
Staining Mycoplasma colonies. To observe Mycoplasma colonies and differentiate between $\mathrm{MyCO}$ plasma and bacterial L-form colonies, isolated Mycoplasma colonies were stained with Dienes stain (Timms 1967). A light film of Dienes stain was placed on a microscopic slide and allowed to dry. A block of agar containing Mycoplasma colonies was cut from MA and placed colony-side upwards on the dry Dienes stained microscope slide (Carter 1975). The preparation was then examined under the low power of a microscope.

Purification of Mycoplasma. Isolated Mycoplasma were purified by the single colony technique (Stalheim 1984). A single colony was removed by cutting out a small block of agar using a sterile scalpel. The colony was transferred to a tube containing $3 \mathrm{ml}$ of MBM and incubated for $48 \mathrm{~h}$. The culture was then passed through a $0.45 \mu \mathrm{m}$ filter, diluted $1 / 10$ and $1 / 100$ in MBM and $50 \mu$ of each dilution was spotted onto MA plates and incubated at $37^{\circ} \mathrm{C}$ in a humidified atmosphere with $5 \% \mathrm{CO}_{2}$ for $7 \mathrm{~d}$. This purification procedure was repeated 3 times.

Biochemical tests. The tests for breakdown of carbohydrates, arginine and urea, reduction of 2,3,5-triphenyltetrazolium chloride (aerobically and anaerobically), phosphatase activity and film and spot production were performed as described by Aluotto et al. (1970). Because of wide variation in the sensitivity of mycoplasma to methylene blue, this characteristic was investigated by adding $0.002 \%(\mathrm{w} / \mathrm{v})$ methylene blue to the MA and comparing the growth of inoculated mycoplasma with the growth of mycoplasma cultivated on MA plates without methylene blue (Fallon \& Whittlestone 1969). All plates and tests were incubated at $37^{\circ} \mathrm{C}$ in a humidified atmosphere with $5 \% \mathrm{CO}_{2}$ for $7 \mathrm{~d}$ unless otherwise stated.

Sugar fermentation. One percent $(w / v)$ of each sugar (mannitol, dulcitol, xylose, sorbitol, arabinose, mannose, sucrose, sorbose, cellubiose, maltose, glucose) was added to $10 \mathrm{ml}$ of $\mathrm{MBM}$ without glucose, then inoculated with $300 \mu$ l of culture medium containing the isolate and incubated. Basal medium without sugar was also inoculated as a growth and $\mathrm{pH}$ indicator control.

Salt concentration. The salt concentration in $10 \mathrm{ml}$ of MBM was adjusted to $1,1.5,2,2.5,3,3.5$ and $4 \%$ (w/v) by addition of extra sodium chloride to MBM at $\mathrm{pH} 7.8$. Then it was inoculated with $300 \mu$ l of culture medium containing the isolated Mycoplasma and other Mycoplasma species listed in Table 1 and incubated. Normal MBM, containing $0.5 \%$ sodium chloride, was also inoculated as a growth and $\mathrm{pH}$ indicator control.

Arginine utilisation. One percent ( $w / v)$ arginine hydrochloride was added to $10 \mathrm{ml} \mathrm{MBM}$ containing $0.4 \%$ phenol red and adjusted to $\mathrm{pH} 7.0$. It was then inoculated with $300 \mu$ l of culture medium containing the isolated Mycoplasma. Basal medium without arginine was also inoculated and incubated as a growth and $\mathrm{pH}$ indicator control.

Haemolysis of red blood cells. Haemolytic activity of each isolated Mycoplasma was tested on mycoplasma blood agar prepared by incorporating sheep red blood cells into the melted $\mathrm{MA}$ at $50^{\circ} \mathrm{C}$ and at a final concentration of $5 \%(\mathrm{v} / \mathrm{v})$ red cells.

Sterol requirement. This test was carried out to discriminate the families Mycoplasmataceae (sterol dependent) from Acholeplasmataceae (sterol independent) by cultivation of the Mycoplasma isolates in MBM without added serum (i.e. with no sterol).

Digitonin test. This test was carried out to discriminate Mycoplasma isolates from Acholeplasma, as Mycoplasma are more sensitive to lysis and to growth inhibition by digitonin than Acholeplasma (Razin \& Shafer 1969). The digitonin discs were prepared by dissolving $0.15 \mathrm{~g}$ of digitonin (Sigma Chemical Co.) in $10 \mathrm{ml}$ of pure ethanol over a boiling water bath. The $6 \mathrm{~mm}$ Whatman filter discs were soaked in $25 \mu \mathrm{l}$ of digitonin solution and then air dried. An MA plate was flooded with $500 \mu$ l of isolated Mycoplasma culture and the plate was allowed to dry in a biological laminar flow cabinet. The digitonin disc was then placed on the agar surface and the plate was incubated.

Phosphatase test. One $\mathrm{ml}$ of $1 \%(\mathrm{w} / \mathrm{v})$ sodium phenolphthalein diphosphate solution was added to MBM without phenol red and glucose, inoculated with $300 \mu \mathrm{l}$ of culture medium containing the isolated Mycoplasma and incubated. Uninoculated medium was incubated as a negative control. After 3 to $4 \mathrm{~d}$ incubation, $5 \mathrm{~N}$ $\mathrm{NaOH}$ was added at a final concentration of $5 \%$ to all the test tubes. A positive reaction was determined by a pink colour change.

Filtration studies. Filterability of isolated Mycoplasma was determined by membrane filtration (Millipore Corp.) at pore diameters of 0.45 and $0.2 \mu \mathrm{m}$. An unfiltered suspension was used as a control, and this suspension and each filtrate were diluted in 10-fold steps and spread $(100 \mu l)$ on MA plates. After incubation for $72 \mathrm{~h}$ at $37^{\circ} \mathrm{C}$ with $5 \% \mathrm{CO}_{2}$, the number of colonies was counted and calculated.

Reversion experiments. The clones were subcultured 6 consecutive times by using liquid or solid growth medium devoid of ampicillin or any other antimicrobial agent in order to determine whether the organisms reverted to bacterial forms. Agar plates and fluid cultures of all passages were examined for alteration in the morphology of clones and cells, respectively. Also, agar culture colonies of each clone were stained with Dienes stain in order to differentiate Mycoplasma colonies from bacterial L forms (Timms 1967). 
Experimental infection. The pathogenesis of MP1 was tested in a prawn bioassay. The MP1 cultures were grown for $48 \mathrm{~h}$ at $37^{\circ} \mathrm{C}$ in $5 \mathrm{ml}$ of MBM. After growing of the Mycoplasma, a serial dilution was made in $1 \mathrm{ml} \mathrm{MBM}$ and an aliquot spotted on MA. The number of colonies on agar was used to calculate the number of Mycoplasma in broth culture. A total of 60 clinically healthy prawns from research breeding facility stocks with no history of untoward mortalities or abnormalities were used in the experimental infections. They were divided into 6 separate groups. Groups 1 and 2 were injected intramuscularly with $50 \mu \mathrm{l}$ of $\mathrm{MBM}$ containing $10^{6}$ colony-forming units (CFU) Mycoplasma and Groups 3 and 4 were injected with $50 \mu$ l of MBM containing $10^{4}$ CFU Mycoplasma. Groups 5 and 6 were control groups that were injected with only $50 \mu l$ of sterile MBM. Clinical observations were made on all prawns beginning 1 wk prior to experimental infection.

Genomic DNA extraction. Mycoplasma were grown in MBM and DNA was extracted from $200 \mathrm{ml}$ of a late exponential phase culture as previously described (Ghadersohi et al. 1997).

Genomic library construction. For cloning of specific fragments, total DNA from MP1 was completely digested with $M b o 1$ (Promega) and the fragments generated were cloned into the BamHI site of pUC19 (Sambrook et al. 1989). Fresh, competent Escherichia coli JM109 cells were used for transformation with ligation mixtures. Recombinant colonies were grown on 2YT agar containing $150 \mu \mathrm{g}$ ampicillin, $40 \mu \mathrm{g} \mathrm{X-Gal}$ and $0.5 \mathrm{mM}$ IPTG $\mathrm{ml}^{-1}$. Colony hybridisation with a probe prepared from purified MP1 DNA was used to identify colonies of interest. Six such colonies were selected for further evaluation. The size of the cloned fragments was determined and fragments were liberated by HindIII/ECoRI double digestion of the plasmids. The digested DNA was purified and isolated on $2 \%$ agarose gels and used to prepare randomly primed probes for dot blot hybridisation.

Dot blot hybridisation. Five hundred ng of chromosomal DNA from different species of Mycoplasma or an equivalent amount of other bacterial DNA (Table 1) was spotted onto nitrocellulose filters following the instructions of the manufacturer (Hybond$\mathrm{N}+$, Amersham) and fixed by baking in an oven at $80^{\circ} \mathrm{C}$ for $2 \mathrm{~h}$. Radiolabeling of DNA with ${ }^{32} \mathrm{P}$ and hybridisation techniques were as described (Ghadersohi et al. 1997). The membranes were then washed twice in $100 \mathrm{ml}$ of $2 \times \mathrm{SSC}(3 \mathrm{M} \mathrm{NaCl}, 0.3 \mathrm{M}$ $\mathrm{Na}_{3}$ citrate) and twice in $100 \mathrm{ml}$ of
$0.1 \% \mathrm{SSC}$ at room temperature (5 min for each wash) with constant agitation. The radiolabelled probes were detected by autoradiography with Fuji X-Ray film for $18 \mathrm{~h}$ at $-70^{\circ} \mathrm{C}$.

Sequence analysis. To determine the DNA homology of isolated Mycoplasma, 2 recombinant plasmids ( $\mathrm{p} M P 1 / 1-2$ and $\mathrm{pMP} 2 / 10-1$ ) with insert sizes of 340 and 1100 base pairs (bp), respectively, were sequenced. The nucleotide sequences of these fragments were determined using an Applied Biosystems Dye Prism kit following the instructions of the manufacturer.

Development of polymerase chain reaction. The probe prepared from the MP1 DNA fragment retrieved from $\mathrm{pMP} 1 / 1-2$ hybridised only with MP1 chromosomal DNA (Fig. 1). The sequence of this fragment (see Fig. 4) was used to design 2 primers which had no similarity with any sequence contained in GenBank or the EMBL DNA database. These were forward $5^{\prime}$-CTCTGCACTATCTGATCAGTA-3' and reverse 5'-GAATTGGGGCTGGTGAAGTAA-3'. They were used to produce a $254 \mathrm{bp}$ amplicon under optimal conditions.

Optimisation of the PCR. To gain maximum sensitivity and specificity, all parameters of the polymerase chain reaction (PCR) were optimised. The amplification was performed in $25 \mu$ l reaction mixture containing $2.5 \mu 10 \times$ PCR buffer, $10 \mu \mathrm{M}$ of each primer, $0.1 \mathrm{mM}$ concentration of each deoxynucleotide triphosphate (dNTP), $3 \mathrm{mM} \mathrm{MgCl}_{2}$ and $1 \mathrm{U}$ Taq DNA polymerase (Bresatec, Australia) in $1 \mu \mathrm{l}$. One droplet of mineral oil was layered on the reaction mixture to prevent evaporation. The reaction was performed in 38 cycles using the following optimal temperature protocol for the 254 bp MP1 fragment: initial denaturation for $5 \mathrm{~min}$ at $94^{\circ} \mathrm{C}$ followed by cyclic denaturation at $94^{\circ} \mathrm{C}$ for $1 \mathrm{~min}$, primer annealing at $60^{\circ} \mathrm{C}$ for $1 \mathrm{~min}$, primer extension at $72^{\circ} \mathrm{C}$ for $1 \mathrm{~min}$ and final extension at $72^{\circ} \mathrm{C}$ for $7 \mathrm{~min}$.

PCR specificity and sensitivity. Twenty ng of chromosomal DNA from MP1 strains was used as the template in a MP1-primed PCR. One hundred ng of DNA

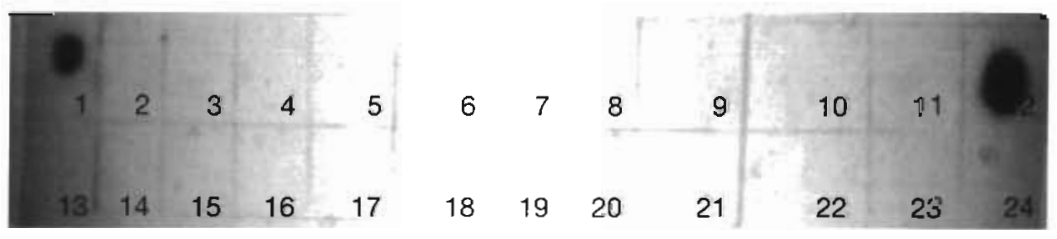

Fig. 1. Autoradiograph of a dot blot hybridisation of various Mycoplasma spp. and bacterial DNAs with the radiolabelled probe $M P 1 / 1-2.1 . M P 1 ; 2: M P 2 ; 3: M$ bovis; 4: $M$. arginini $i_{i}$ : $M$. ovipneumoniae; $6: M$ agalactiae $7: M$. bovigenitalium; 8: $M$. bovirhinis; 9: $M$. dispar; 10: Mycoplasma Group $7 ; 11: M$. bovigenitalium; 12: positive control recombinant plasmid MP1/1-2; 13: Vibrio sp.; 14: Pseudomonas putida; 15: Streptococcus uberis; 16: Staphylococcus aureus; 17: Corynebacterium bovis; 18: Klebsiella pneumoniae; 19: Aeromonas sp.; 20: Escherichia colli 21: Enterobacter cloacae; 22: Enterobacter facalis; 23: Yersinia enterocolitica; 24 : Serratia marcescens 
from MP2, pUC19 plasmid and other Mycoplasma and bacteria (Table 1) was also subjected to MP1 PCR to determine the specificity of the test. To determine the sensitivity of the test samples of DNA prepared by phenol-chloroform, extraction from a known amount of mycoplasma (CFU) in broth culture was subjected to MP1 PCR.

Clinical samples. To test the PCR with field material, purified DNA from diseased prawns from aquaculture farms in northern Queensland was subjected to MP1 PCR. Homogenised organ materials (gill appendages, brain and eyes) from individual prawns were initially suspended in $1 \mathrm{ml}$ NTE buffer $(10 \mathrm{mM} \mathrm{NaCl}, 20 \mathrm{mM}$ Tris hydrochloride $\mathrm{pH} 7.4,1 \mathrm{mM}$ EDTA) and incubated overnight at $37^{\circ} \mathrm{C}$ with $0.5 \%$ sodium dodecyl sulphate (SDS) and $100 \mu \mathrm{g}$ of proteinase $\mathrm{K}$ (Promega) $\mathrm{ml}^{-1}$. DNA was extracted with phenol-chloroform as described previously (Ghadersohi et al. 1997). To remove any inhibitors of PCR, the DNA was purified using the Wizard Minipreps DNA purification system (Promega).

\section{RESULTS}

\section{Culture of clinical samples}

Some of the cultures were overgrown by bacterial contamination with Corynebacterium spp. It was found that these bacteria could pass through $0.45 \mu \mathrm{m}$ membrane filters. Mycoplasma were recovered from $14 / 24$ moribund prawns and from none of 20 healthy prawns or from negative control cultures. The Mycoplasma isolated decreased the $\mathrm{pH}$ of $\mathrm{MBM}$ and formed typical 'fried egg' Mycoplasma colonies on Mycoplasma agar. The colonies rapidly stained with Dienes reagent, confirming that the isolates were true Mycoplasma (members of the Mollicutes) rather than bacterial L forms (Timms 1967). Liquid cultures stained with Giemsa stain contained characteristic mycoplasmal pleomorphic forms (Klieneberger-Nobel 1962). The isolated Mycoplasma were resistant to low $\mathrm{pH}$ (4.7) as measured from growth and subculture on MBM and MA for several months.

\section{Biochemical tests}

The MP1 and MP2 were able to ferment all sugars (MP2 variably) but they did not utilise arginine and urea (Table 2). They grew at 20 and $37^{\circ} \mathrm{C}$, and did not grow in the absence of bovine serum. MP1 produced films and spots on MA containing $10 \%$ (v/v) homogenized egg yolk and it had a strong positive phosphatase reaction, but MP2 did not produce films and spots and had no phosphatase activity. Both strains lysed sheep erythrocytes and grew with or without $\mathrm{CO}_{2}$ at $37^{\circ} \mathrm{C}$, but growth was faster at $37^{\circ} \mathrm{C}$ with $5 \%$ $\mathrm{CO}_{2}$. No dye reduction occurred when they were grown in MBM containing $0.025 \%(\mathrm{w} / \mathrm{v})$ tetrazolium chloride. While the reference Mycoplasma from animal origin failed to grow in $M B M$ with increased sodium chloride, the Mycoplasma isolated from prawns grew in MBM containing sodium chloride from 0.5 to $3 \%$

In digitonin tests to discriminate Mycoplasma from Acholeplasma, the zone of inhibition for the prawn

Table 2. Biochemical characteristics of 3 Mycoplasma reference strains and 2 Mycoplasma strains isolated from Penaeus monodon. N: not tested

\begin{tabular}{|c|c|c|c|c|c|}
\hline Characteristic & MP1 & $M P 2$ & M. mobile & M. phocarhinis ${ }^{b}$ & M. phocacerebrale \\
\hline Fermentation of glucose & + & $+1-$ & + & - & - \\
\hline Fermentation of lactose & + & + & + & $\mathrm{N}$ & $\mathrm{N}$ \\
\hline Fermentation of mannitol, dulcitol xylose, sorbitol & + & + & $\mathrm{N}$ & $\mathrm{N}$ & $\mathrm{N}$ \\
\hline Fermentation of arabinose, mannose, saccharose & + & + & + & $\mathrm{N}$ & $\mathrm{N}$ \\
\hline Fermentation of sorbose, cellubiose & + & + & $\mathrm{N}$ & $\mathrm{N}$ & $\mathrm{N}$ \\
\hline Fermentation of maltose & + & + & + & $\mathrm{N}$ & $\mathrm{N}$ \\
\hline Hydrolysis of arginine & - & - & - & - & + \\
\hline Hydrolysis of urea & - & - & - & - & - \\
\hline Reduction of 2,3,5-triphenyltetrazolium chloride & - & - & + & + & - \\
\hline Reduction of methylene blue & - & - & - & - & - \\
\hline Phosphatase activity & + & - & $+1-$ & + & + \\
\hline Production of film and spots & + & - & + & + & + \\
\hline Haemolysis ovine erythrocytes & + & + & + & + & + \\
\hline Growth at $20^{\circ} \mathrm{C}$ & + & + & + & $\mathrm{N}$ & $\mathrm{N}$ \\
\hline Growth at $30^{\circ} \mathrm{C}$ & + & + & + & $\mathrm{N}$ & $\mathrm{N}$ \\
\hline Growth at $37^{\circ} \mathrm{C}$ & + & + & - & + & + \\
\hline Growth in high salt $(3 \%)$ & + & + & $\mathrm{N}$ & $N$ & $\mathrm{~N}$ \\
\hline
\end{tabular}


Mycoplasma strains was 18 to $30 \mathrm{~mm}$. The zone of inhibition increased with increasing concentration of the stock culture and decreased with increasing incubation time. The isolated Mycoplasma were able to pass through membrane filters of $0.45 \mu \mathrm{m}$ pore size without reduction in number and through filters of $0.2 \mu \mathrm{m}$ with a slight reduction in number. They did not revert to bacterial forms during 6 consecutive passage in media lacking inhibiting antibiotic substances.

\section{Experimental infections}

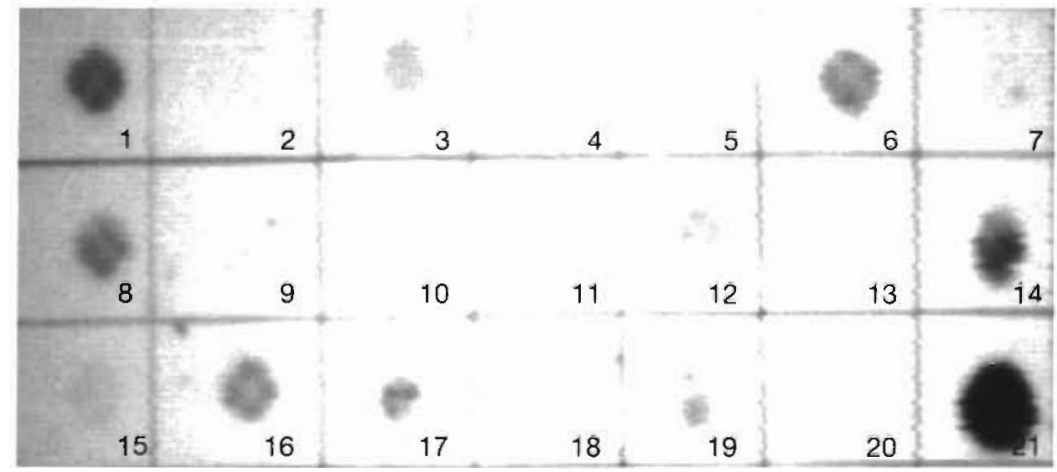

Fig. 2. Autoradiograph of a dot blot hybridisation of DNA of moribund prawns with the probe MP1/1-2.1-19: DNA samples from 19 individual moribund prawns collected from farms; 20: negative control; 21 : positive control recombinant plasmid containing MP1/1-2

After challenge with $10^{6}$ CFU MP1 (Groups 1 and 2), cumulative mortality by Day 17 was 5/10 for Group 2 (i.e. 2 on Day 4,2 on Day 10 and 1 on Day 17) (Table 3). Mycoplasma were isolated from the eye and gill appendages of 3 of the dead prawns, but cultures from the other 2 prawns were overgrown with contaminating bacteria. Also, on Day 14, 2 prawns from control Groups 5 and 6 died but no Mycoplasma were found, and cultures were overgrown with contaminating bacteria. On Day 30, 2 prawns from Group 4 died (i.e. challenged with $10^{4}$ CFU Mycoplasma). Mycoplasma was isolated from only 1 by culture, but Mycoplasma DNA was detected in both by PCR (Table 3). There was significantly higher mortality in Group $4\left(10^{6} \mathrm{CFU}\right.$ challenge) than in both the $10^{4} \mathrm{CFU}$ challenge groups ( 3 and 4) and the control groups (5 and 6) $\left\{\chi^{2}=4.5, \mathrm{p}<0.05, \mathrm{df}=1\right\}$ (Zar 1974). On Day 60, 5 prawns each from Groups 1 and 2, 4 prawns each from Groups 3 and 4 and 2 prawns each from the control Groups 5 and 6 were sacrificed. Mycoplasma were isolated from 3 of the 5 prawns from Group 1 $\left(10^{6} \mathrm{CFU}\right)$ but cultures from the other groups were negative (Table 3).

Table 3. Results from experimental injection of Penaeus monodon with $\mathrm{Myco}$ plasma P1 (MP1). PCR was performed only on prawns that died and were negative on culture

\begin{tabular}{|lcccccc|}
\hline & $\begin{array}{c}\text { Group 1 } \\
10^{6} \text { CFU }\end{array}$ & Group 2 & Group 3 & Group 4 & Group 5 & Group 6 \\
& $10^{4}$ CFU & $10^{4}$ CFU & Control & Control \\
\hline Mortality & $5 / 10$ & & $2 / 10$ & $1 / 10$ & $1 / 10$ \\
$\begin{array}{l}\text { Positive on culture } \\
\text { Positive by PCR }\end{array}$ & $3 / 5$ & & $1 / 10$ & 0 & 0 \\
At termination of experiment $(60 \mathrm{~d})$ & & $2 / 2$ & $0 / 1$ & $0 / 1$ \\
Positive on culture & $3 / 5$ & $0 / 5$ & $0 / 4$ & $0 / 4$ & $0 / 2$ & $0 / 2$ \\
\hline
\end{tabular}

\section{Identification of a specific probe}

The Mbo1 digests of MP1 were constructed into pUC19 plasmid vector. Based on colony hybridisation, 6 white colonies giving high intensity staining with MP1 whole genomic DNA were selected for detailed study. After double digestion, 8 fragments ranging in size from 0.1 to $2 \mathrm{~kb}$ were purified and used to prepare probes for dot blot hybridisation. One fragment of $340 \mathrm{bp}$ called MP1/1-2 was found to hybridise with MP1 only (Fig. 1) and not with DNA from other microorganisms (Table 1). Using fragment MP1/1-2 as a probe in dot blot hybridisation tests, most of the isolated prawn Mycoplasma ( $80 \%)$ were identified as strain MP1 (Fig. 2).

\section{Sensitivity of the probe}

To check the sensitivity of the probe MP1/1-2, homogenised tissue from a healthy prawn which was negative by dot blot hybridisation (i.e. prawn No. 2, Fig. 2) was seeded with known CFU of MP1 followed by dot blot hybridisation tests. The results are shown in Fig. 3. The detection limit of this assay was approximately $10^{3} \mathrm{CFU}$. As can be seen in Fig. 3, the size and intensity of the dot blot reaction increased with increasing numbers of Mycoplasma in the homogenate.

\section{DNA sequencing and primer determination for PCR}

A computer search of GenBank and EMBL databases for sequence simi- 

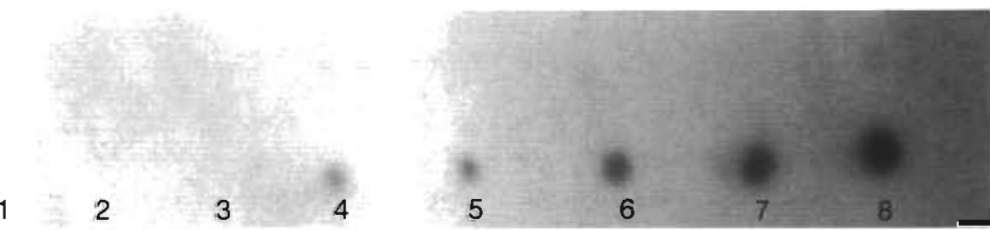

Fig. 3. Sensitivity of the DNA probe MP1/1-2 in the dot-blot procedure. Dilutions of a preparation of Mycoplasma (MP1) with a known titre were added to a crude homogenised healthy prawn sample No. 2 (see Fig. 2), and then extracted DNA from the experimentally seeded samples was subjected to the dot-blot procedure. Samples contained (1) 10 , (2) $10^{2}$, (3) $5 \times 10^{2}$, (4) $10^{3}$, (5) $10^{4}$, (6) $10^{5}$, (7) $10^{6},(8) 10^{7} \mathrm{CFU} \mathrm{ml}^{-1}$ of prawn isolated Mycoplasma

\begin{abstract}
5'-GGATCTGTTT TCATATCATT AATTAGTTTA GTTCCTTGCA TATTTCCATA TTTATACTCT GCACTATCTG ATCAGTATGG AGTTGACATT TGAACTAATT GGTTAACTGG TGTAAATGGA ATTAATACAG CAGCTAGACA AATAGCAATI GTTGCAATTA ACATTGATCC ATTGTAGCAA TTGTATTAAC ATGCACTCCC ATATCTCTTC ATTTACTCAT TGGTATTTTA TATAAAGGAA T TGAATAGTA TGTTCCTTTA TTAGTAATTA ACATTAAATG TTGTAAGTTG CTTACTTCAC CAGCCCCAAT TCACATATCA TT TGGTTTTC TTCCAAATAC-3'
\end{abstract}

Fig. 4. Nucleotide sequence of the 340 bp MP1 DNA fragment. The sequences corresponding to the primers used for PCR are shown in bold and underlined These nucleotide sequences have been deposited in the GenBank, EMBL Nucleotide Sequence databases under the accession number AF042859, NCBI REF 374530

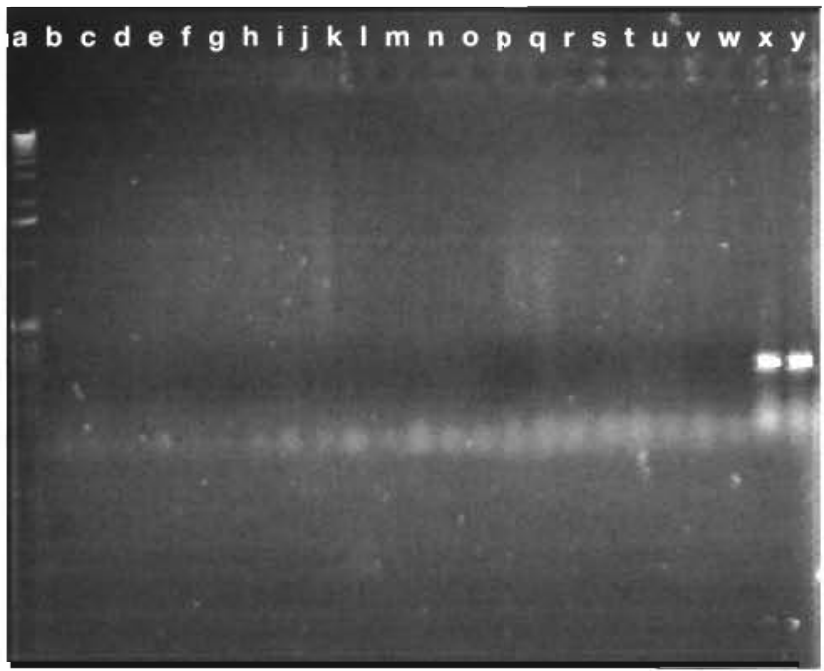

Fig. 5. Photograph of a $1.8 \%$ agarose electrophoresis gel showing the PCR amplification reaction products using various genomic DNA samples. Lane a: molecular weight markers (MWM) (BRL $1 \mathrm{~kb}$ ladder); Lane b: Staphylococcus aureus; Lane c: Staphylococcus spp.; Lane d: Aeromonas spp.; Lane e: Streptococcus agalactiae; Lane f: Corynebacterium bovis; Lane g: Serratia marcescens; Lane h: Enterobacter cloacae; Lane i: Klebsiella pneumoniae; Lane j: Pseudomonas spp.; Lane k: Vibrio spp.; Lane l: Yersinia enterocolitica; Lane m: Mycoplasma bovirhinis; Lane n: Mycoplasma Group 7; Lane o: Mycoplasma ovipneumoniae; Lane p: Mycoplasma arginini; Lane q: Mycoplasma dispari Lane r: Mycoplasma agalactiae; Lane s: Mycoplasma bovigenitalium; Lane t: Mycoplasma bovirhinis; Lane u: Mycoplasma bovis (type strain); Lane v: MP2; Lane w: no template; Lane x: isolated Mycoplasma (MP1); Lane y: recombinant pUC19 (positive control)

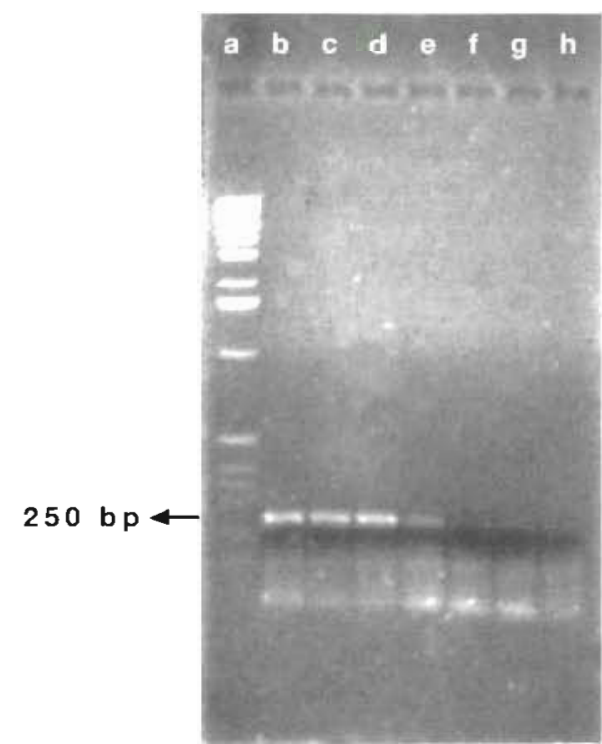

Fig. 6. Photograph of a $1.8 \%$ agarose electrophoresis gel showing the PCR amplification reaction products using various dilutions of MP1 genomic DNA. Lane a: MWM (1 kb ladder); DNA was extracted from: Lane b, $10^{7}$; Lane $\mathrm{c}, 10^{3}$; Lane d, 500; Lane e, 300; Lane f, 100; Lane g, 10 CFU of MP1; Lane h has no template

larity was conducted. Both Mycoplasma fragments retrieved from recombinant plasmids gave $70 \%$ homology with Mycoplasma capricolum DNA for CONTIG MC095 and 61\% protein similarity with (Z33071) DNA-gyrase (alpha) of $M$. capricolum. The sequence of the MP1 insert is shown in Fig. 4.

\section{Sensitivity and specificity of MP1 PCR}

Samples of $20 \mathrm{ng}$ of DNA prepared by phenolchloroform extraction from prawn isolated $\mathrm{MyCo}$ plasma were used as templates for MP1 PCR and the expected $254 \mathrm{bp}$ amplicon was obtained. By contrast, 100 ng DNA templates from MP2, 8 other bovine and ovine Mycoplasma species and other bacteria (Table 1) gave no amplicoans under the same PCR conditions (Fig. 5). The sensitivity of the MP1 PCR was for homologous DNA from $300 \mathrm{CFU}$, as determined by $1.8 \%$ agarose gel electrophoresis (Fig. 6). The PCR assay was validated by using DNA from the same diseased prawns that were used in the hybridisation assay (shown in Fig. 2). The PCR assays confirmed the results of the hybridisation assays and a sample from these PCR tests is shown in Fig. 7. 


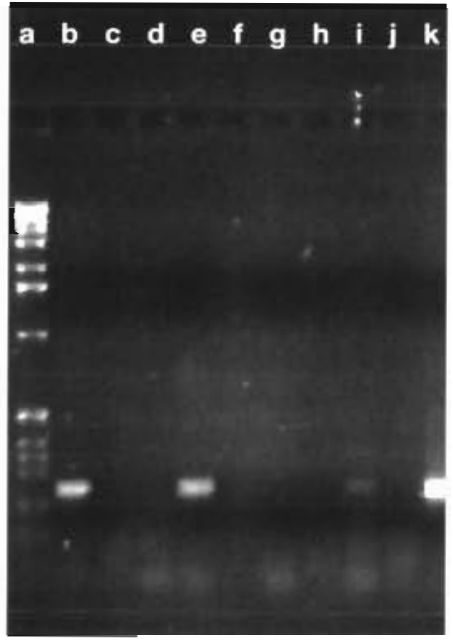

Fig. 7. Agarose electrophoresis gel $(1.8 \%)$ of PCR amplification products from DNA samples of individual moribund prawns from aquaculture farms in northern Queensland. A subset of DNA samples ( 8 of the 19) was drawn from the same lot used in the hybridisation assay for Fig. 2. Lane a: MWM (1 kb ladder); Lane b: prawn 1; Lane c: prawn 2; Lane d: prawn 3; Lane e: prawn 8 ; Lane f: prawn 10; Lane g: prawn 11; Lane h: prawn 12; Lane i: prawn 13; Lane j: negative control; Lane $k$ : positive control recombinant plasmid

\section{DISCUSSION}

The properties of the organisms isolated from diseased prawns fulfilled the essential criteria for Mollicutes as proposed by the International Committee on Systematic Bacteriology Subcommittee on Taxonomy (1995), i.e. typical fried-egg colony form, polymorphic cell form, absence of a cell wall, passage through 0.45 and $0.2 \mu \mathrm{m}$ filters, lack of reversion to bacteria, resistance to ampicillin. According to digitonin sensitivity and serum requirement, they could be classified in the family Mycoplasmataceae. The inability to hydrolyse urea indicated that the organisms did not belong to the genus Ureaplasma. The most exciting property of the isolated Mycoplasma strains was their ability to grow in Mycoplasma media containing 3.0\% sodium chloride and to tolerate low $\mathrm{pH}$ (4.7) for a long period. These properties appear to be unique, because other Mycoplasma species fail to grow in such media. The Mycoplasma isolates grew over a wide range of temperatures.

Some Mycoplasma spp., such as Mycoplasma mobile isolated from fish, can adhere to glass and plastic surfaces (Kirchhoff et al. 1987) but in this study no such adherence was observed. Furthermore, there was no DNA hybridisation reaction between MP1 and Mycoplasma from other animals. Using a DNA probe and PCR amplification, most of the prawn Mycoplasma iso- lates $(\sim 80 \%)$ corresponded to strain MP1. From the results presented here, it is suggested that the prawn Mycoplasma isolates represent 2 new species. This was confirmed by $16 \mathrm{~S}$ r RNA gene sequencing, the results of which will be presented elsewhere.

The Mycoplasma in the experimentally infected prawns did not produce high mortalities. This is not surprising since most Mycoplasma diseases are influenced by a variety of host and environmental factors. Moreover, avirulent strains occur naturally and some animals can carry Mycoplasma with no signs of disease until they are stressed (Simecka et al. 1992). However, the isolation of pure Mycoplasma from the eyes, gill appendages and brain of dead prawns suggests that MP1 might have some potential to produce disease or predispose the prawns to other viruses and bacteria. Further studies on the route of infection and the loss of virulence during passage in artificial medium (Tully \& Razin 1983, Wadler et al. 1990, Miles 1992) are needed.

Current methods used to diagnose Mycoplasma infections are inadequate because they lack speed, sensitivity and specificity (Simecka et al. 1992). Since DNA probes and PCR can overcome these problems (Razin 1994), we used these methods to design a specific DNA probe and PCR test to separate the Mycoplasma isolates from some previously described Mycoplasma species. We obtained a DNA clone (MP1/1-2) that was relatively sensitive (i.e. $10^{3} \mathrm{CFU}$ $\mathrm{ml}^{-1}$ ) and highly specific for the detection of $M P 1$. We also found a direct relationship between Mycoplasma number and intensity of hybridisation dot, so that rough quantitation was possible. Although the sensitivity might be regarded as low, it may be adequate for the detection of active infections even in poorly preserved samples. On the other hand, the use of radionucleotide DNA labeling may be restrictive, since it is not easily adapted to routine laboratory usage. Nevertheless, the probe did not cross react with other microorganisms likely to be found in association with diseased prawns

The PCR method we developed based on MP1/1-2 was highly specific for detection of Mycoplasma DNA in prawns since it gave no amplicons even with $100 \mathrm{ng}$ concentrations of DNA (corresponding to $10^{7} \mathrm{CFU}$ ) from heterologous Mycoplasma species (Razin 1994) or from other bacteria. In tests of the PCR assay, no background problems through interference by proteins, fats, haemolymph and ions present in prawn tissue were encountered, and the concurrence of results with those from the hybridisation assay indicated that no false positive or false negative results were obtained. At $300 \mathrm{CFU}$, it was 10 times more sensitive than the dot blot hybridisation test for Mycoplasma DNA detection and it may be more easily applied in shrimp disease diagnostic laboratories. Using the PCR and dot blot 
tests, some prawns were shown to be free of MP1 infection, but the data also indicated infections in prawns from 2 farms $500 \mathrm{~km}$ apart. Further investigations should be undertaken on broodstock to determine whether they can be the source of Mycoplasma infections. Large-scale screening of prawns is now possible through the highly sensitive and specific PCR

Acknowledgements. This research was funded by James Cook University and a Fisheries Research and Development Corporation grant $96 / 301$. The nucleotide sequence data reported in this paper have been deposited in the EMBL, GenBank Nucleotide Sequence databases under the accession number AF042859, NCBI REF 374530

\section{LITERATURE CITED}

Aluotto B, Wittler RG, Williams CO, Faber JE (1970) Standardized bacteriological techniques for the characterization of Mycoplasma species. Int J Syst Bacteriol 20:35-58

Carter GR (1975) Diagnostic procedures in veterinary microbiology. Charles C Thomas, Springfield, IL

Fallon RJ, Whittlestone P (1969) Isolation cultivation and maintenance of Mycoplasma. In: Norris J, Ribbons OW (eds) Methods in microbiology, Vol 3B. Academic Press, Inc, New York, p 211-267

Frey ML, Hanson RP, Anderson DP (1968) A medium for the isolation of avian Mycoplasmas. Am J Vet Res 29:2163

Ghadersohi A, Coelen RJ, Hirst RG (1997) Development of a specific DNA probe and PCR for the detection of $\mathrm{Myco}$ plasma bovis. Vet Microbiol 56:87-98

Giebel J, Meter A, Binder J, Flossdorf JB, Poveda R, Schmidt $\mathrm{R}$, Kirchhoff H (1991) Mycoplasma phocarhinis sp. nov. and Mycoplasma phocacerebrale sp. nov., two new species from Harbor Seals (Phoca vitulina L.). Int J Syst Bacteriol 41:39-44

Herderschee D (1963) An improved medium for the cultivation of Eaton agent. Antonie van Leeuwenhoek 29:154-156

International Committee on Systematic Bacteriology Subcom-

Editorial responsibility: Timothy Flegel

Bangkok, Thailand mittee on the Taxonomy (1995) Revised minimum standards for the description of new species of the class Mollicutes (Division Tenerricutes). Int $\mathrm{J}$ Syst Bacteriol 45: $605-612$

Kirchhoff $\mathrm{H}$, Beyene $\mathrm{P}$, Fischer $M$, Flossdorf $J$, Heitmann $J$, Khattab B, Lopatta D, Rosengatten R, Seidel G, Yousef C (1987) Mycoplasma mobile sp. nov, a new species from fish. Int J Syst Bacteriol 37:192-197

Klieneberger-Nobel E (1962) Pleuropneumonia-like organisms (PPLO). Mycoplasmataceae. Academic Press, Inc, New York

Miles RJ (1992) Cell nutrition and growth. In: Maniloff $J$, McElhaney R, Finch L, Baseman J (eds) Mycoplasmas molecular biology pathogenesis. American Society for Microbiology, Washington, DC, p 23-40

Razin S (1994) DNA probes and PCR in diagnosis of $M y c o-$ plasma infection. Mol Cell Probes 8:497-511

Razin S, Shafer Z (1969) Incorporation of cholesterol by membranes of bacterial L-phase variants. J Gen Microbiol 58 : $327-339$

Sambrook J, Fritsch EF, Maniatis T (1989) Molecular cloning. A laboratory manual. Cold Spring Harbor Laboratory, Cold Spring Harbor, NY

Simecka JW, Davis JK, Davidson MK, Ross SE, Stadtlander CT, Cassell GH (1992) Mycoplasma diseases of animals. In: Maniloff J, McElhaney R, Finch L, Baseman J (eds) Mycoplasmas: molecular biology and pathogenesis. American Society for Microbiology, Washington, DC, p 391-415

Stalheim OHV (1984) Mycoplasmas in animals. In: Carter GR (ed) Diagnostic procedures in veterinary bacteriology and mycology, Vol 27. Charles C Thomas, Springfield, IL, p 263-288

Timms L (1967) Isolation and identification of avian Mycoplasmas. J Med Lab Technol 24:79-89

Tully JG, Razin S (1983) Methods in mycoplasmalogy, Vol II, Diagnostic mycoplasmalogy. Academic Press, New York

Wadler BJ, Henderson CL, Miles RJ, Varsani H (1990) A mutant of Mycoplasma mycoides subsp. mycoides lacking the $\mathrm{H}_{2} \mathrm{O}_{2}$-producing enzyme $\mathrm{L}$ - a-glycerophosphate oxidase. FEMS Microbiol Lett 72:127-130

Zar JH (1974) Biostatistical analysis. Prentice Hall, Englewood Cliffs, NJ

Submitted: November 3, 1997; Accepted: August 27, 1998

Proofs received from author(s): November 22, 1998 